\title{
THE WHITE-CLAWED CRAYFISH, AUSTROPOTAMOBIUS PALLIPES, IN GREAT BRITAIN AND IRELAND WITH PARTICULAR REFERENCE TO ITS CONSERVATION IN GREAT BRITAIN.
}

\author{
D.M. HOLDICH and W.D. ROGERS \\ Department of Life Science, The University of Nottingham, \\ Nottingham, England NG7 2RD.
}

\begin{abstract}
Great Britain and Ireland still contain some of the best stocks of Austropotamobius pallipes in Europe despite the fact that since the early 1980 s many populations have been devastated by the effects of crayfish plague and competitive exclusion by non-native crayfish.
\end{abstract}

Austropotamobius pallipes is the only crayfish native to Great Britain and Ireland but in recent years a number of introductions of foreign crayfish have been made into Great Britain, for aquacultural, culinary and aquarist purposes. This has resulted in four non-native crayfish species becoming established in the wild, where two, Pacifastacus leniusculus and Astacus leptodactylus, have formed large, harvestable populations, particularly in southern England.

Although $A$. pallipes in Great Britain and Ireland is protected by national and European legislation, this has not been enough to protect it from crayfish plague and, in Great Britain, from non-native crayfish. In an attempt to protect $A$. pallipes even further, legislation has been implemented in England, Scotland and Wales which bans the keeping of all non-native crayfish, except where they are being prepared for human consumption. P. leniusculus is, however, exempt from this ban in certain parts of southern Great Britain due to its high preponderance on crayfish farms and in the wild. Ireland already bans the introduction of non-native crayfish.

It is hoped that the new legislation, plus the heightened profile which $A$. pallipes has recently been given in Great Britain, will ensure its future survival.

Key-words : Austropotamobius pallipes, Pacifastacus leniusculus, Astacus leptodactylus, crayfish plague, conservation, legislation.

\section{L'ÉCREVISSE À PATTES BLANCHES, AUSTROPOTAMOBIUS PALLIPES, EN GRANDE-BRETAGNE ET EN IRLANDE ET LES PROBLĖMES DE SA CONSERVATION EN GRANDE-BRETAGNE.}

\section{RÉSUMÉ}

La Grande-Bretagne et l'Irlande possèdent encore les meilleurs stocks d'Austropotamobius pallipes en Europe bien que, depuis les années 80 , beaucoup de ses populations aient été décimées à cause de la peste des écrevisses et que son exclusion ait été provoquée par la compétition des écrevisses non indigènes.

Austropotamobius pallipes est la seule écrevisse autochtone présente en Grande-Bretagne et en Irlande mais, ces dernières années, des écrevisses exotiques ont été introduites en Grande-Bretagne pour des objectifs d'aquaculture, de gastronomie et 
d'aquariophilie. La conséquence a été l'établissement de quatre espèces d'écrevisses non indigènes dans la nature où, en particulier, Pacifastacus leniusculus et Astacus leptodactylus ont formé de grandes populations exploitables dans le sud de l'Angleterre.

Bien que $A$. pallipes soit protégée en Grande-Bretagne et en Irlande par une législation nationale et européenne, ce n'est pas suffisant pour la protéger de la peste et, en Grande-Bretagne, des écrevisses exotiques. Dans le but de protéger encore mieux A. pallipes, une législation a été appliquée en Angleterre, en Ecosse et au Pays de Galles en interdisant de garder les écrevisses exotiques, sauf si elles ont été préparées pour la consommation. Cependant, $P$. leniusculus échappe à cette interdiction dans certaines parties du sud de la Grande-Bretagne à cause de sa grande prépondérance dans les astacicultures et dans la nature. ' L'Irlande vient juste d'interdire l'introduction d'écrevisses exotiques.

Nous pouvons espérer que la nouvelle législation en vigueur ainsi que les efforts de sensibilisation pour $A$. pallipes favoriseront sa survie dans le futur.

Mots-clés : Austropotamobius pallipes, Pacifastacus leniusculus, Astacus leptodactylus, peste de l'écrevisse, conservation, législation.

\section{BACKGROUND}

Ever since HUXLEY's (1879 and later editions) book entitled «The Crayfish - an introduction to the study of Zoology", which was largely based on the white-clawed crayfish, Austropotamobius pallipes (Lereboullet, 1858), there has been a strong interest in this animal amongst researchers, educationalists and the general public. A. pallipes became a standard animal for dissection in British schools and universities until the 1950 s but it was then perceived to be declining in numbers and became less popular (CORNISH, 1902 ; DUFFIELD, 1933 ; PIXELL GOODRICH, 1956). Many publications relating to various aspects of the biology of $A$. pallipes in Great Britain and Ireland have been produced since HUXLEY's book and these are listed in Table I under subject headings and the bibliography.

In recent years, much concern has been expressed about the status of $A$. pallipes in Great Britain and Ireland. Threats to its future survival have been highlighted by $\mathrm{HOLDICH}$ (1991) and HOLDICH and REEVE (1991). Consequently, many recent studies have concentrated on the possible impact of these threats and ways by which they might be alleviated. Most notable amongst the threats were those from crayfish plague, caused by the fungus, Aphanomyces astaci Schikora, and the invasion of the freshwater environment by non-native crayfish.

\section{Table I}

Selected works relating to studies on Austropotamobius pallipes in Great Britain and Ireland, listed under subject headings (see bibliography for references).

\section{Tableau I}

Principaux travaux portant sur l'étude d'Austropotamobius pallipes en Grande-Bretagne et en Irlande, classés par thème et cités dans la bibliographie.

\section{Behaviour \\ Holdich et al. (1995c), Ingle (1979), Pond (1975).}

Conservation/management

Diseases
Department of the Environment (1995), Groombridge (1993), Holdich et al. (1995a, b), Holdich and Reeve (1991), Holdich and Rogers (1992), Naura and Robinson (1997), Reynolds and Matthews (1997), Rogers and Holdich (1995b, 1997).

Alderman (1993), Alderman and Polglase (1988), Alderman et al. (1984, 1986, 1987, 1990), Bowler (1979), Cossins (1973), Cossins and Bowler (1974), Duffield (1933), 


\section{Distribution/Ecology}

Farming/harvesting

General Biology

Genetics
Growth/Morphometrics

Impact of foreign crayfish

Physiology/Biochemistry/

Toxicology

\section{Population dynamics}

Reproduction/Fecundity

\section{Structure}

Taxonomy/Identification
Foster and Slater (1995), Holdich et al. (1995b), Holdich and Reeve (1991), Lowery and Hogger (1986), Lowery et al. (1986), Marren (1986), Matthews and Reynolds (1990, 1992), O'Keeffe and Reynolds (1983), Pixell Goodrich (1956), Reynolds (1988a), Slater et al. (1995).

Albrecht (1982, 1983), Baker (1983), Cornish (1902), Duffield (1933, 1936), Faris (1936), Foster (1993, 1995), Goddard and Hogger (1986), Hogger and Lowery (1982), Holdich (1996), Holdich et al. (1995b), Holdich and Reeve (1991), Huxley (1878, 1879), Jay and Holdich (1981), Laurent (1988), Lilley et al. (1979), Lowery and Hogger (1986), Lowery and Holdich (1988), Lucey and McGarrigle (1987), Matthews and Reynolds (1992, 1995b), Matthews et al. (1993), McFadden and Fairly (1984), Moriarty (1972), Reynolds (1979b, 1982), Rutty (1772), Slater (1995), Slater and Foster (1987) Slater and Rayner (1993), Slater et al. (1995), Smith et al. (1996), Thomas (1992), Thomas and Ingle (1971), Thompson (1843).

Holdich (1993), Holdich and Rogers (1992), Holdich et al. (1995b), Reynolds (1979a, 1988b, 1989a, b), Reynolds and Matthews (1993), Rhodes and Holdich (1979, 1984), Rogers and Holdich (1995a).

Environment Agency (1997), Gledhill et al. (1993), Holdich (1991, 1992, 1996), Holdich et al. (1978), Holdich and Lowery (1988), Holdich et al. (1995b), Huxley (1878, 1879), National Rivers Authority (1994).

Attard and Vianet (1985), Grandjean et al. (1997a, b). Bowler and Brown (1977), Brewis and Bowler (1982), Brown and Bowler (1979), Lowery (1988), Pratten (1980), Reynolds (1989a), Rhodes and Holdich $(1979,1984)$, Thomas (1983).

Holdich (1988, 1991), Holdich and Domaniewski (1995), Holdich et al. (1995a, b).

Bowler et al. (1973), Bryan (1960a, b, c), Firkins and Holdich (1993), Foster and Turner (1993), Hoidich et al. (1997), Jay and Holdich (1977), Middleton et al. (1996), Shaw (1959, 1960a, b, c), Sutcliffe and Carrick (1975), Taylor and Wheatly $(1980,1981)$, Wheatly and Taylor (1981), Whiteley et al. (1993).

Brewis (1979), Brewis and Bowler (1983), Brown and Bowler (1977), Brown and Brewis (1979), Pratten (1980), Thomas and Ingle (1971).

Brewis and Bowler (1985), Ingle and Thomas (1974), Lowery (1988), Matthews and Reynolds (1995a), Rhodes (1981), Rhodes and Holdich (1982), Thomas (1977, 1983), Woodlock and Reynolds (1988a, b).

Holdich and Reeve (1988), Huxley (1879), Thomas (1970, 1977, 1979, 1986).

Albrecht (1982), Environment Agency (1997), Gledhill et al. (1993), Gordon (1963), Holdich (1991), Huxley (1878, 1879), Thomas and Ingle (1971), National Rivers Authority (1994). 


\section{CURRENT STATE OF KNOWLEDGE}

\section{Distribution}

The distribution of $A$. pallipes in Great Britain and Ireland based on all records for the period 1970-1996 inclusive is shown in Figure 1. A. pallipes seems to be naturally absent from Scotland, south-west England and western Wales but has a wide-spread distribution in the rest of England and in Ireland. It mainly inhabits clean, relatively hard, mineral-rich waters with a $\mathrm{pH}$ between 7 and 9 and calcium concentrations above $5 \mathrm{mg} \mathrm{l}^{-1}$ (GLEDHILL et al., 1993). It occurs in a wide range of habitats including lakes, reservoirs and water-filled quarries, as well as in rivers and . streams. It can occur in very small streams as long as there is a good water flow. The highest known population occurs at 400 metres altitude in Malham Tarn (Yorkshire). SMITH et al. (1996) and NAURA and ROBINSON (1997) have recently identified those habitat features which are most important for $A$. pallipes.

Until the work of THOMAS and INGLE (1971), no attempt had been made to summarise the distribution of $A$. pallipes in Great Britain and Ireland. Subsequently, more detailed information has been gathered for Great Britain by JAY and HOLDICH (1981), GODDARD and HOGGER (1986), HOLDICH and REEVE (1991) and HOLDICH et al. (1995 b). These studies led to the setting up of a national database which is regularly updated. REYNOLDS (1979 b, 1982) reviewed the situation for Ireland and this was updated and expanded by LUCEY and McGARRIGLE (1987), but few records have been forthcoming since.

Figure 1 shows the minimum potential distribution for $A$. pallipes. The maximum potential distribution could be somewhat greater as there are many areas which, despite having apparently suitable habitats, have never had recorded populations of $A$. pallipes in recent times, e.g. the chalk streams of the South Downs in England. A. pallipes has, however, been introduced into parts of western Wales and northern Scotland this century and viable populations have developed (THOMAS, 1992 ; HOLDICH et al., 1995 b). The current distribution for Great Britain is shown in Figure 2 and it can clearly be seen that many populations seem to have disappeared, particularly in southern England. This is largely due to the impact of crayfish plague (see below). However, recent surveys have indicated that there are in fact still many large populations of $A$. pallipes in England and Wales, particularly in the north of England.

The origin of $A$. pallipes in Great Britain and Ireland is not clear. The earliest published records do not occur until the mid-1600s, although crayfish appear to have been wide-spread in southern England at least at that time (THOMAS and INGLE, 1971). ALBRECHT (1983) is of the opinion that $A$. pallipes could not have survived the last ice-age in Great Britain but that it may have recolonised southern England either naturally through post-glacial streams connecting to France or via human introductions. According to THIENEMANN (1950), the British Isles were linked to mainland Europe via a land bridge until 6000 years ago and the rivers of southern England met with the original Rhine, the Seine, Somme, Authie and Cauche. ALBRECHT (1983) has suggested that $A$. pallipes may have been introduced into Ireland and quotes GERSTFELDT (1859) as stating that they were released there at the beginning of the 19th century. This cannot be the case, however, as REYNOLDS (1979 b) quotes literature giving records from the $1700 \mathrm{~s}$ and 1800 s, when they were thought to be already wide-spread. REYNOLDS (1979 b) and LAURENT (1988) favour a natural post-glacial colonisation of Ireland by $A$. pallipes. However, low genetic variability has been found amongst $A$. pallipes populations in Great Britain by GRANDJEAN et al. (1997 a) possibly suggesting a relatively recent colonisation. In addition, ATTARD and VIANET (1985) found a genetic similarity between some French and Irish A. pallipes populations, and GRANDJEAN et al. (1997 b) found a genetic similarity between French and English/Welsh populations of $A$. pallipes, although different genetic markers were used by the two groups of workers. This low genetic variability, plus the similarity to French stock, indicate that crayfish in Great Britain and Ireland may have been introduced by man. The genetic similarity of British populations has implications for the future management of the species (see below). 


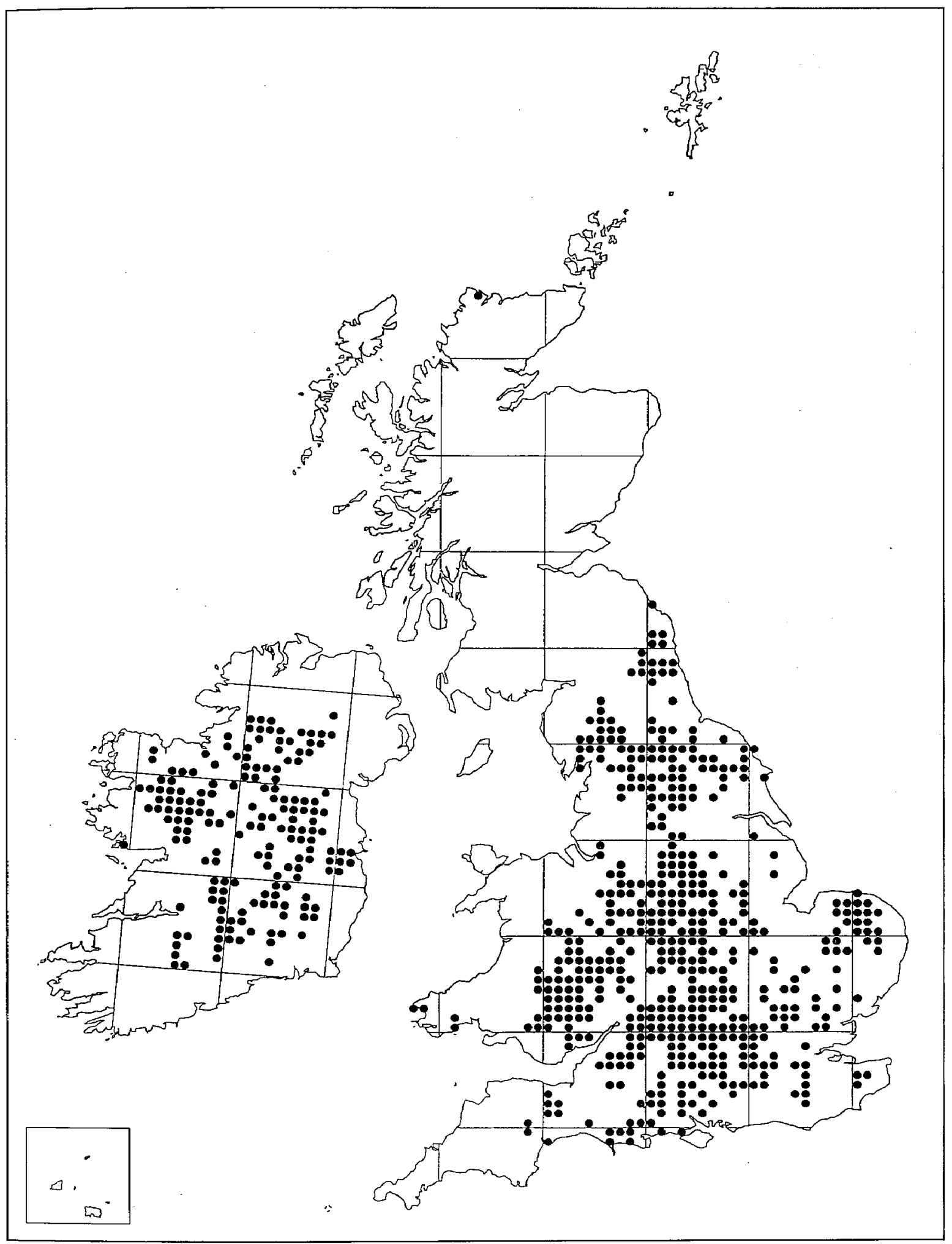

Figure 1

Distribution of Austropotamobius pallipes in Great Britain and Ireland shown at the 10-km square level for the period 1970-1996 inclusive.

Figure 1

Distribution d'Austropotamobius pallipes par quadrat de $10 \mathrm{~km}^{2}$ en Grande-Bretagne et en Irlande à partir des données récoltées pendant la période de 1970 à 1996 (inclus). 


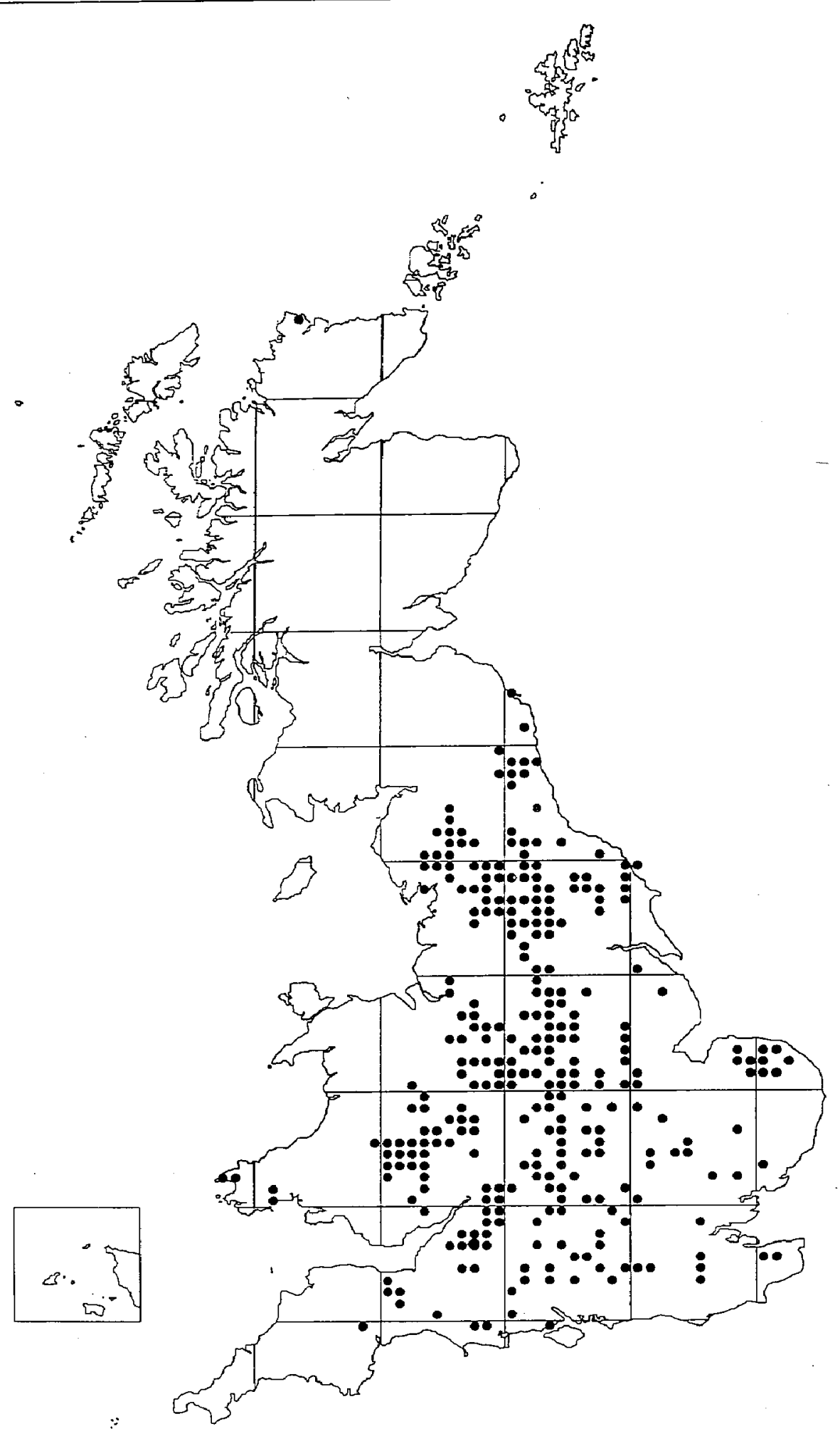

Figure 2

Distribution of Austropotamobius pallipes in Great Britain shown at the 10-km square level for the period 1990-1996 inclusive.

Figure 2

Distribution d'Austropotamobius pallipes par quadrat de $10 \mathrm{~km}^{2}$ en Grande-Bretagne à partir des données récoltées pendant la période de 1990 à 1996 (inclus). 


\section{Threats to survival}

A number of authors have mentioned that populations of A. pallipes in Great Britain and Ireland have been subject to fluctuations in numbers, possibly due to disease (DUFFIELD, 1933, 1936 ; FARIS, 1936 ; PIXELL GOODRICH, 1956 ; MORIARTY, 1972). However, there is little to suggest that these are anything other than natural events or ones caused by man's alteration of the crayfish's environment by pollution and waterway management schemes such as channelisation, particularly since the Industrial Revolution. Pollution and drought events regularly have a devastating effect on $A$. pallipes populations but they often recover due to recolonisation from headwater or tributary populations (HOLDICH, 1991; HOLDICH and REEVE, 1991). Random pollution events, particularly of silage and biocides, pose an ever present threat to A. pallipes.

Unfortunately, the apparent decline of $A$. pallipes populations in Great Britain, coupled with their susceptibility to crayfish plague, plus the fact that they are slow-growing, small and with low fecundity (RHODES and HOLDICH, 1979, 1982), encouraged the introduction of plagueresistant, fast-growing, large and fecund foreign crayfish as an alternative species, which also had aquaculture potential (RICHARDS and FUKE, 1977 ; RICHARDS, 1983 ; HOGGER, 1986 a, b). The impact that these introductions might have on the remaining $A$. pallipes populations, not least the fact that they could be carrying the crayfish plague fungus, was initially highlighted by BOWLER (1979).

The successful culture of the North American signal crayfish, Pacifastacus leniusculus (Dana), in southern England led to a demand for it and many implants were made in England and Wales from the mid-1970s onwards. Most of the early implants were into existing fish farm ponds or lakes but some were directly into the wild as, at the time, there was no legislation to stop this. There are very few purpose-built crayfish farms in Great Britain and much of the production comes from extensive systems (HOLDICH and ROGERS, 1992 ; ROGERS and HOLDICH, 1995 a). Escapes occurred from ponds and lakes and these led to the further development of wild populations. Implants met with variable success in population establishment but those which did survive have led to a wide-spread distribution of $P$. leniusculus, particularly in southern England (Fig. 3). These populations pose a threat to the future survival of $A$. pallipes. As many as 100 premises were registered as crayfish farms in the early 1990s (ROGERS and HOLDICH, 1995 a), but only a few farmers made a good profit from their ventures and many have since deregistered and now only 14 are active (A. SCOTT, pers. comm.). Farmed production of $P$. leniusculus is currently probably less than 10 tonnes (HOLDICH and ROGERS, 1992 ; ROGERS and HOLDICH, 1995 a). However, the wild catch of the non-native crayfish $P$. leniusculus and Astacus leptodactylus (see below), which was insignificant until recently, is now making an increasing contribution to total production in Great Britain, and may soon overtake that produced by farming (ROGERS and HOLDICH, 1995 a).

Since the early 1980 s, many populations of $A$. pallipes have been lost in England and Wales due to the effects of crayfish plague (see summary in ALDERMAN, 1993). In addition, a severe outbreak in Ireland in the mid-1980s eliminated huge numbers of $A$. pallipes despite the fact that no introductions of $P$. leniusculus had been permitted (REYNOLDS, 1979 a, 1988 a, b ; MATTHEWS and REYNOLDS, 1995 b). Figure 4 indicates those catchments which have been affected. No natural recovery of eliminated populations has yet occurred but those reintroductions which have been attempted have proved successful (HOLDICH et al., 1995 b). No outbreak of crayfish plague has occurred since 1993 and many of those waters previously affected and, where the threat no longer exists, could be restocked.

The distribution of $A$. pallipes and $P$. leniusculus now overlaps in many parts of England and Wales (Figures 2 and 3 ) and some water bodies previously inhabited by $A$. pallipes are now occupied by $P$. leniusculus. Although mixed populations of the two species have developed, none survived for more than five years even though the $P$. leniusculus were free of the crayfish plague fungus. The loss of the $A$. pallipes in these cases is most likely to have been due to competitive exclusion and predation by $P$. leniusculus (HOLDICH and DOMANIEWSKI, 1995 ; HOLDICH et al., $1995 \mathrm{c})$. 


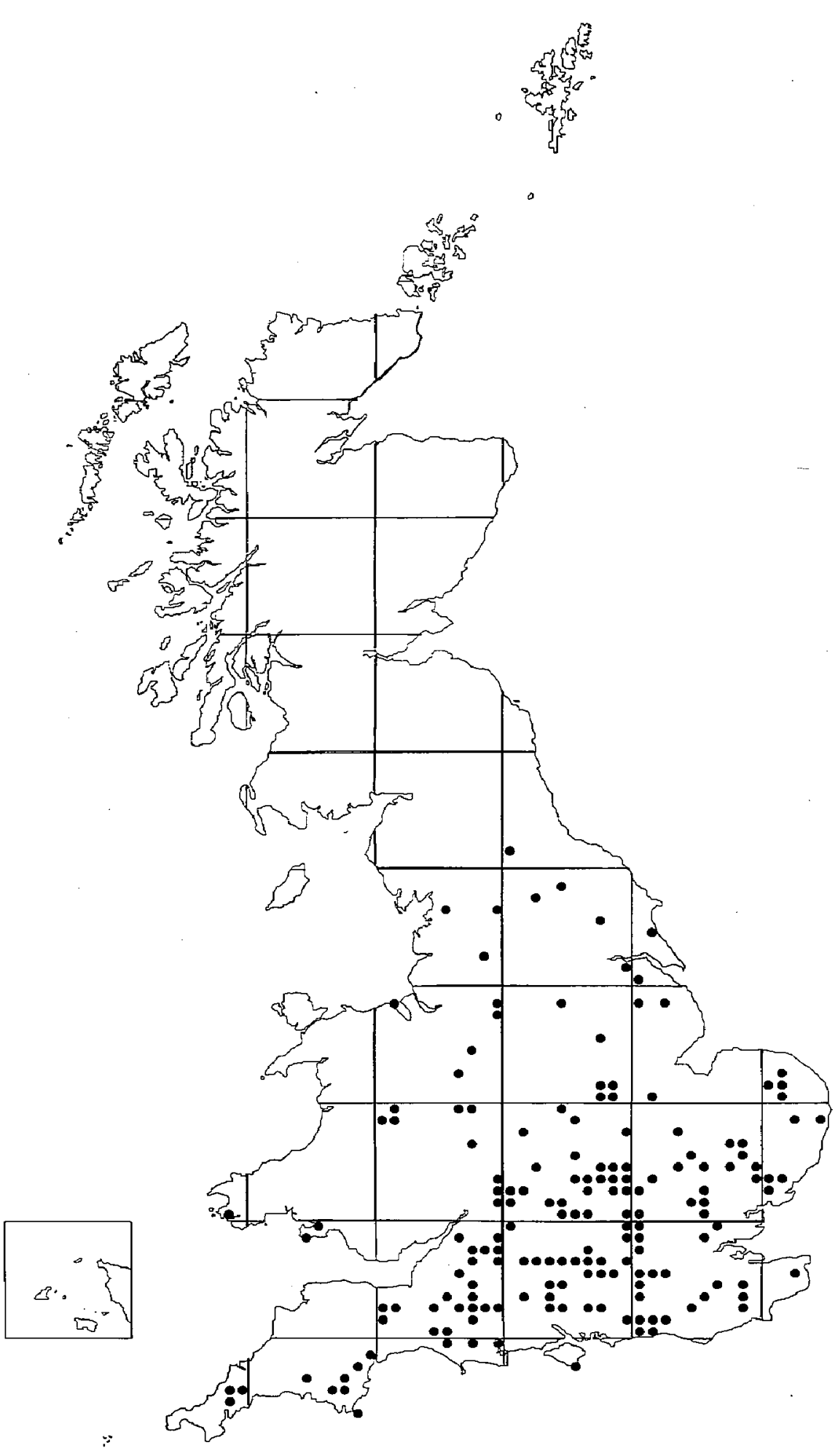

\section{Figure 3}

Distribution of Pacifastacus leniusculus in Great Britain shown at the 10-km square level for the period 1990-1996 inclusive.

Figure 3

Distribution de Pacifastacus leniusculus par quadrat de $10 \mathrm{~km}^{2}$ en Grande-Bretagne à partir des données récoltées pendant la période de 1990 à 1996 (inclus). 


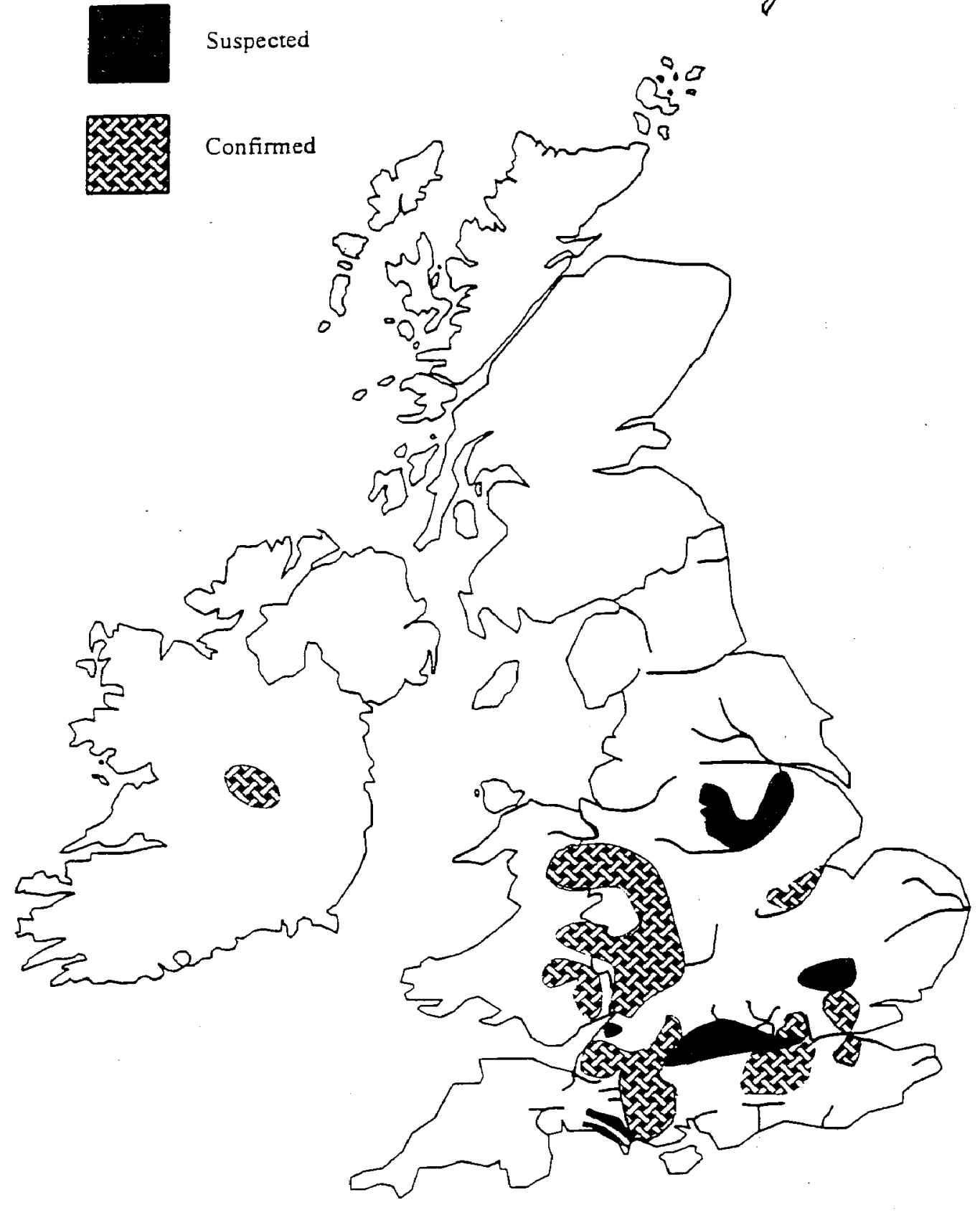

Figure 4

Catchments in Great Britain and Ireland which have suffered mortalities of Austropotamobius pallipes since 1980 which are thought to have been due to crayfish plague.

Figure 4

Bassins en Grande-Bretagne et en Irlande où ont été observées des mortalités d'Austropotamobius pallipes depuis 1980 et dont on suppose qu'elles sont dues à la peste des écrevisses. 
As well as the effects $P$. leniusculus is having on $A$. pallipes, there is also concern about its impact on the freshwater environment in general due to its burrowing activities (GUAN, 1994; HOLDICH et al., 1995 b), its high densities (GUAN and WILES, 1996), its ability to move over relatively long distances (GUAN and WILES, 1997), and its feeding habits (HOLDICH et al., 1995 b).

In addition to $P$. leniusculus, a number of other foreign crayfish species have become established in Great Britain, all of which could pose a threat to $A$. pallipes in the future if they are not controlled.

The narrow-clawed (Turkish) crayfish, Astacus leptodactylus Eschscholtz, introduced into Great Britain in the 1970s mainly for the restaurant trade, has a less extensive distribution than $P$. leniusculus, being mainly confined to the south-east of England (HOLDICH et al., $1995 \mathrm{~b}$ ). It is not farmed to any extent and most of the populations are wild having been deliberately introduced.' As with $P$. leniusculus, it is much larger, more fecund and invasive than $A$. pallipes, but like it is susceptible to the effects of crayfish plague.

The other species of non-native crayfish found in Great Britain have a very limited distribution at present (details are given in HOLDICH et al,, 1995 b). The noble crayfish, Astacus astacus (L.), from mainland Europe is only known in one area in south-west England where it occurs on a farm and in the wild. $A$. astacus grows to a larger size and is more fecund than $A$. pallipes but, like it, is susceptible to crayfish plague. The red swamp crayfish, Procambarus clarkii (Girard), originally from Louisiana (USA) but mainly reaching Great Britain via the aquarist trade, has only become established at one site in London. However, individual specimens have been found in the wild in other parts of England, sometimes carrying eggs. The red swamp crayfish is a fast-growing, highly fecund, invasive species, which can carry the crayfish plague fungus. Its rapid spread in mainland Europe is causing great concern. The spiny-cheeked or striped crayfish, Orconectes limosus (Rafinesque), originally from North America but now very common in mainland Europe, has yet to be confirmed as present in Great Britain, although it is rumoured to be. It has similar characteristics to the red swamp crayfish, including the ability to carry the crayfish plague fungus. Various Australian crayfish belonging to the genus Cherax have been introduced into Great Britain from time to time. No wild populations have yet developed.

\section{Legislation}

In Great Britain, it is illegal to take $A$. pallipes from the wild (without a licence) or sell it as it is listed on Schedule 5 of the Wild life and Countryside Act, 1981, which gives it protection from such activities. Equivalent protection operates in Northern Ireland. In the Republic of Ireland, it is protected by the Wildlife Act, 1976, and it cannot be interfered with, nor can its habitat, without a licence. It is also included in the IUCN Red Data List (GROOMBRIDGE, 1993) and in Appendix III of the Bern Convention and Annexes II and V of the European Habitats Directive. The directive requires the designation of protected areas (Special Areas of Conservation) for species in Annex II.

It is illegal under Section 14 of the Wildlife and Countryside Act, 1981 to release (without a licence) into the wild non-native crayfish species in Great Britain. However, for farming purposes, $P$. leniusculus may be introduced if a licence is obtained from the Ministry of Agriculture, Fisheries and Food (MAFF). The areas where farming may be sanctioned by MAFF have recently (1996) been restricted to the southern Great Britain (see below). It is also illegal to allow non-native crayfish species to escape from holding facilities - reasonable steps and due diligence must be exercised to avoid this. Due to their perceived threat to $A$. pallipes, three non-native species (A. astacus, A. leptodactylus and P. leniusculus) were listed on Schedule 9 of the Wildlife and Countryside Act in 1992, which effectively classifies them as pests and to which Section 14 (above) of the Act still applies, despite the fact that they are now ordinarily resident in the wild. If other non-native crayfish are found to be breeding in the wild (e.g. P. clarkii), then they will be added to the list. In addition to the above legislation, persons producing crayfish for sale or transfer are required to register under a 1985 Order of The Diseases of Fish Act. No prosecutions have ever been made relating to the release of non-native crayfish to the wild, because there has not been a satisfactory definition of the "wild". However, MAFF have now decided that, as far as crayfish are concerned, the wild shall be defined as - any body of water from which crayfish could move to a natural water course (A. SCOTT, pers. comm.). This has serious implications for existing crayfish farms, as very few are escape-proof. Unless prosecutions are brought against people contravening the laws then escapes will continue to occur and pose a threat to the native crayfish. 
In May 1996, MAFF and the Welsh Office introduced further measures to protect A. pallipes by means of «The Prohibition of Keeping of Live Fish (Crayfish) Order 1996». It is not possible for Great Britain to restrict the import of crayfish from mainland Europe due to GATT regulations but, by this Order of the Import of Live Fish Act, MAFF can determine what happens to them once they are imported. The new measures aim to prevent the spread of $P$. leniusculus by designating prohibited areas (no-go areas) for crayfish farming in parts of England and Wales (Fig. 5). Parallel legislation has been introduced by the Scottish Office to make the whole of Scotland a no-go area for all non-native crayfish species. In no-go areas, the unlicensed keeping of $P$. leniusculus will be banned, although the few crayfish farms in operation will be allowed to continue as long as they adhere to the terms of the Wildlife and Countryside Act (see above). The regulations also ban the unlicensed keeping of all other non-native crayfish species throughout Great Britain. There is an exemption from the new regulations for those keeping non-native crayfish for direct human consumption. A Code of Practice (MINISTRY OF AGRICULTURE, FISHERIES AND FOOD, 1996) has been produced for fish markets, hotels and restaurants advising them how to keep live crayfish securely, and of their legal responsibilities. Outside of no-go areas, $P$. leniusculus can be sold by aquarist centres and kept in aquaria, but over Great Britain as a whole, only the tropical red-clawed crayfish from Queensland, Cherax quadricarinatus (von Martens), has been given an exemption from the new legislation, and can be kept in closed, heated aquaria. The importation of crayfish into the Irish Republic is prohibited under the Live Fish (restriction of import) Order 1972 of the Fisheries Acts. The introduction of non-native crayfish into Northern Ireland is an offence under the Wildlife (Northern Ireland) Order 1985.

The Environment Agency is currently undertaking a national review of Fisheries Bylaws. A new bylaw which may be implemented is one banning the use of live or dead crayfish as bait. This would give further protection to $A$. pallipes as it would reduce the number of accidental introductions of non-native crayfish and the spread of crayfish plague by this means. Another new bylaw being proposed is one which would prohibit the fishing for crayfish without written consent, except on sites registered as crayfish farms. This bylaw is mainly concerned with regulating the use of traps (including fyke nets) which might spread crayfish plague and accidentally or deliberately catch $A$. pallipes, or fish protected under Section 6 of the Salmon and Freshwater Fisheries Act (1975).

\section{Conservation}

In recent years, there has been a concerted effort to protect the remaining stocks of A. pallipes in Great Britain and Ireland. In Great Britain, the government has accepted the fact that crayfish plague and non-native crayfish pose threats to the future survival of $A$. pallipes. Legislation (see above), in addition to that in the Wildlife and Countryside Act, has been recently introduced to try and control the problem. Also, research into the distribution of the native and non-native crayfish has been funded so that the overall status is well known and future trends can be monitored (HOLDICH et al., 1995 b).

The terms of the EC Habitats Directive and the fact that the Government signed up to the Biodiversity Convention at the 1992 Rio Earth Summit have resulted in the statutory and voluntary conservation bodies in Great Britain taking a much greater interest in protecting species such as A. pallipes at a local level, particularly as $A$. pallipes is one of 116 plant and animal species identified as of key importance in the UK Biodiversity Action Plan Steering Group Report (DEPARTMENT OF THE ENVIRONMENT, 1995).

Educating people about the crayfish problem in Great Britain has been important in ensuring the future survival of $A$. pallipes. This has been helped by the wide-spread dissemination of leaflets which summarise the problem and hejp with the identification of the species present (NATIONAL RIVERS AUTHORITY, 1994 ; ENVIRONMENT AGENCY, 1997).

All river catchments in England and Wales have recently been categorised on the basis of their crayfish status (HOLDICH and ROGERS, 1997). This information should assist managers in deciding what further measures need to be taken to protect and conserve populations of $A$. pallipes. Amongst these measures, two are fundamental to any management policy, i.e. restocking and stocking native crayfish, and eradication of non-native crayfish. 


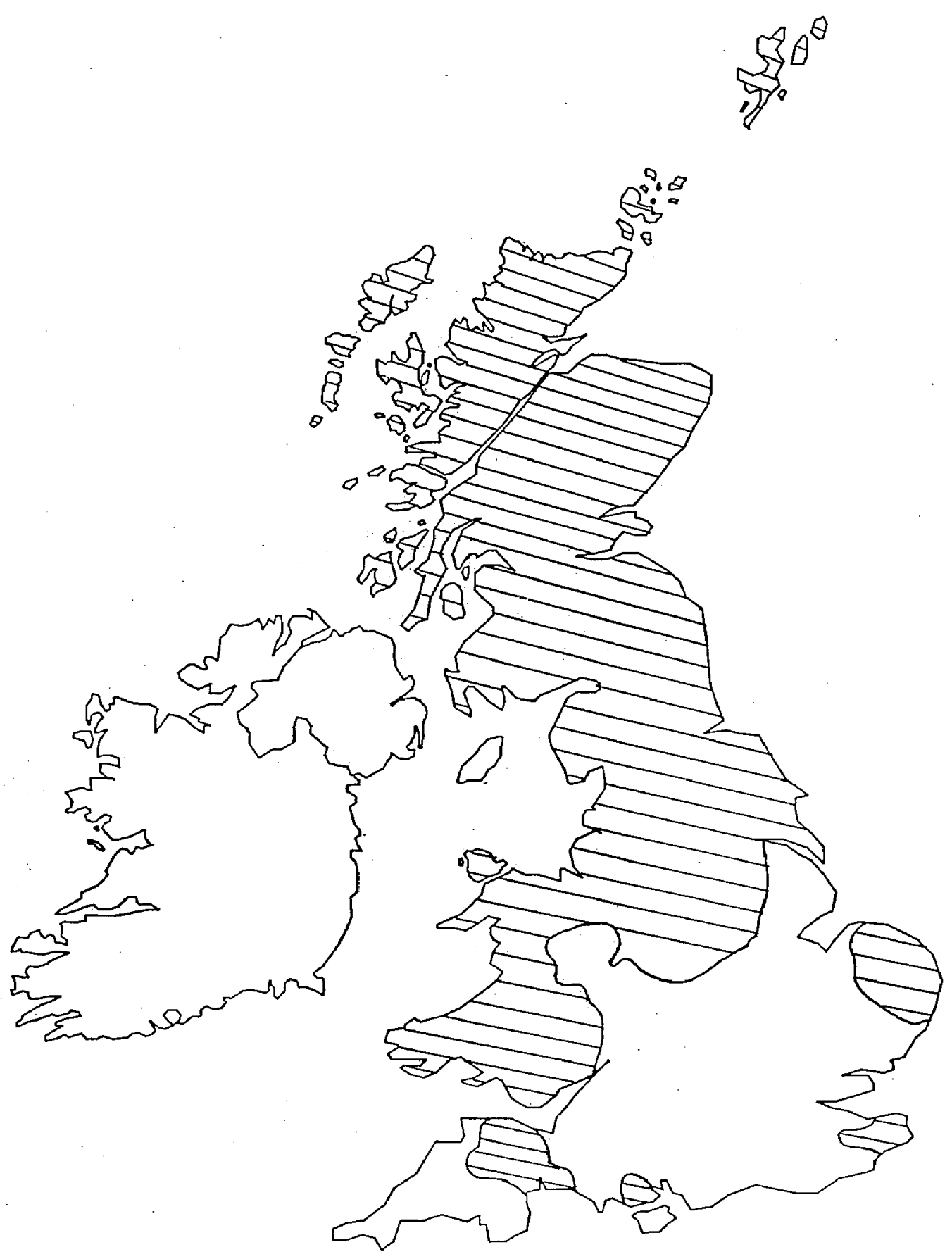

Figure 5

Areas of Great Britain to which The Prohibition of Keeping of Live Fish (Crayfish) Order 1996 applies. Shaded portions are no-go areas for the keeping of Pacifastacus leniusculus. It is not permitted to keep any other species of foreign crayfish in the whole of Great Britain but see text for exemptions.

Figure 5

Zones en Grande-Bretagne où s'exerce la loi de 1996 interdisant de garder des écrevisses exotiques vivantes. Les portions hachurées correspondent à des zones interdites pour l'élevage de Pacifastacus leniusculus. II n'est pas permis de garder toute autre espèce d'écrevisses exotiques dans tout le pays mais se référer au texte pour les dérogations. 


\section{Restocking and stocking}

Restocking of waters previously affected by crayfish plague has been carried out in the Bristol Avon catchment (England) (M. FRAYLING, pers. comm.) and an Irish lake (REYNOLDS and MATTHEWS, 1997). These have both been successful in that breeding populations have become established. Attempts are being made to cultivate $A$. pallipes using local stock to restock the River Itchin (England), where crayfish are thought to have been eliminated by crayfish plague in the 1980s (A. HUTCHINGS, pers. comm.). In these cases, local stock has been used but in other cases this might not be possible. GRANDJEAN et al. (1997 b) have shown, by the mitochondrial DNA technique, that $A$. pallipes in Great Britain are very similar to those in France, suggesting that British populations may have originally been derived from French stock. Also, this may have been relatively recently as little genetic variation has been found between British populations (GRANDJEAN et al., 1997 a). Although these studies were fairly conclusive, further work is needed using a greater range of samples and additional techniques before one can say that reintroductions can be made using stock from non-local populations. When possible, local stock should be used for reintroductions, although this is no guarantee that they will have the same genetic structure, as stocking waters where $A$. pallipes has not been recorded before was common practice in the past (THOMAS and INGLE, 1971). This was carried out at a time when A. pallipes was a popular food and is probably partly responsible for the present distribution pattern. Such introductions are not permitted now under the terms of the Wildlife and Countryside Act, 1981, except under licence. The practice of adding crayfish to a water body should be viewed with caution (HOLDICH, 1988) and, if it is attempted, particular note should be taken of their habitat requirements (SMITH et al., 1996; NAURA and ROBINSON, 1997). TAUGB $\varnothing$ L et al. (1993) have pointed out that when crayfish plague eradicates a crayfish population, then a valuable genetic resource may be lost. One way of preventing this is to protect a plague-threatened population by transferring part of it to a non-threatened site. Consequently, if the main population was eradicated, the reserve population would serve as a living gene-bank from which restocking material could be obtained. In Norway, where the native crayfish is a valuable resource, this has been carried out with a number of populations.

\section{Eradication of non-native crayfish species}

This should be considered as an option to protect $A$. pallipes in Great Britain, particularly where non-native crayfish occur in catchments with strong native populations. However, no research has been funded in Great Britain to see if this is feasible. Control of such populations is probably a more viable option, particularly by intensive trapping over a sustained period as has been done for $A$. leptodacty/us (HOLDICH et al., 1995 b). However, even control is difficult unless it is carried out at regular intervals as juvenile crayfish are rarely caught by trapping. Another option might be to use predators such as eels. P. leniusculus in particular are able to survive out of water for months in their burrows, so attempts to eliminate lacustrine populations by draining down and then refilling have failed as the time interval was not long enough. There is no biocide specific for crayfish and the use of such chemicals has met with little success (LAURENT, 1995).

\section{CONCLUSIONS}

It has taken almost two decades to persuade the British Government that established crayfish introductions and crayfish plague are serious threats to the future survival of $A$. pallipes - the only crayfish native to Great Britain. This is now accepted and legislation is being put in place which should enhance the protection of this species. Whether the setting up of no-go areas (ROGERS and HOLDICH, 1997) and the implementation of national bylaws will prove sufficient remains to be seen. Although, the status of $A$. pallipes in Great Britain has improved markedly over the last few years, and there have been no crayfish plague outbreaks for four years, there is no room for complacency and constant vigilance will be required if this is not to deteriorate. Despite the introduction of new laws, very few catchments containing A. pallipes in England and Wales are currently "safe" from the threat of non-native crayfish and crayfish plague. Even the dense populations in the north of England could easily be threatened by an illegal introduction or an outbreak of crayfish plague. It should be noted that a number of $P$. leniusculus crayfish populations are thought to be developing north of the border in Scotland. 
In order to ensure the future survival of $A$. pallipes in Great Britain, priority should be given to funding research in the following areas :

1. Distribution. This is not static and consequently, for any conservation and management plans to succeed, there needs to be continuous monitoring of the situation. Records will need verifying regularly if managers are to be provided with the correct information. The National Database of crayfish records needs to be updated regularly.

2. Eradication. There is an urgent need to develop methods for eradicating nuisance populations of non-native crayfish, particularly in areas where there are strong populations of A. pallipes.

3. More needs to be known about the genetics of $A$. pallipes so that a sensible reintroduction policy can be formulated.

\section{ACKNOWLEDGEMENTS}

The authors would like to thank staff at the ITE Biological Records Centre for producing the $10 \mathrm{~km}$ square distribution maps and the Environment Agency for permission to include certain information in this paper and for funding part of the study.

\section{BIBLIOGRAPHY}

ALBRECHT H., 1982. Das System der europäischen Flusskrebse (Decapoda, Astacidae) : Vorschlag und Berründung. Mitteilungen aus den Hamburgischen Zoologischen Museum und Institut, 79, 187-210.

ALBRECHT H., 1983. Besiedlungsgeschichte und ursprünglich holozäne Verbreitung der europäischen Flusskrebse. Spixiana, 6, 61-77.

ALDERMAN D.J., 1993. Crayfish plague in Britain, the first twelve years. Freshwater Crayfish, 9, 266-272.

ALDERMAN D.J., POLGLASE J.L., FRAYLING M., HOGGER J., 1984. Crayfish plague in Britain. Journal of Fish Diseases, 7, 401-405.

ALDERMAN D.J., FEIST S.W., POLGLASE J.L., 1986. Possible nocardiosis of crayfish Austropotamobius pallipes. Journal of Fish Diseases, 9, 345-347.

ALDERMAN D.J., POLGLASE J.L., FRAYLING M., 1987. Aphanomyces astaci : pathogenicity under laboratory and field conditions. Journal of Fish Diseases, 10, 385-393.

ALDERMAN D.J., POLGLASE J.L., 1988. Pathogens, parasites and commensals. In : HOLDICH D.M., LOWERY R.S. (eds), Freshwater Crayfish : biology, management and exploitation, 67-212, Chapman and Hall, London.

ALDERMAN D.J., HOLDICH D.M., REEVE I., 1990. Signal crayfish acting as vectors in crayfish plague in Britain. Aquaculture, 86, 3-6.

ATTARD J., VIANET R., 1985. Variabilité génétique et morphologique de cinq populations de l'écrevisse européenne Austropotamobius pallipes (Lereboullet, 1858) (Crustacea, Decapoda). Canadian Journal of Zoology, 63, 2933-2939.

BAKER R., 1983. Freshwater crayfish in Norfolk. Transactions of the Norfolk and Norwich Naturalist Society, 26, 163-165.

BOWLER K., 1979. Plague that has ravaged Europe. Fish Farmer, 2 (1), 34-35.

BOWLER K., GLADWELL R.T., DUNCAN C.J., 1973. Acclimatization to temperature and death at high temperatures in the crayfish Austropotamobius pallipes. Freshwater Crayfish, 1 , 121-131.

BOWLER K., BROWN D.J., 1977. Some aspects of growth in the British freshwater crayfish, Austropotamobius pallipes pallipes (Lereboullet). Freshwater Crayfish, 3, 295-308. 
BREWIS J.M., 1979. Dynamics of a population of the freshwater crayfish Austropotamobius pallipes (Lereboullet). Freshwater Crayfish, 4, 153-157.

BREWIS J.M., BOWLER K., 1982. The growth of the freshwater crayfish Austropotamobius pallipes in Northumbria. Freshwater Biology, 12, 187-200.

BREWIS J.M., BOWLER K., 1983. A study of the dynamics of a natural population of the freshwater crayfish Austropotamobius pallipes. Freshwater Biology, 13, 443-452.

BREWIS J.M., BOWLER K., 1985. A study of reproductive females of the freshwater crayfish Austropotamobius pallipes. Hydrobiologia, 121, 145-149.

BROWN D.J., BOWLER K., 1977. A population study of the British freshwater crayfish Austropotamobius pallipes (Lereboullet). Freshwater Crayfish, 3, 33-49.

BROWN D.J., BOWLER K., 1979. The relationship between size and age throughout the life cycle in Austropotamobius pallipes. Freshwater Crayfish, 4, 35-42.

BROWN D.J., BREWIS J.M., 1979. A critical look at trapping as a method of sampling a population of Austropotamobius pallipes (Lereboullet) in a mark and recapture study. Freshwater Crayfish, 4, 159-163.

BRYAN G.W., 1960 a. Sodium regulation in the crayfish Astacus fluviatilis. I. The normal animal. Journal of Experimental Biology, 37, 83-99.

BRYAN G.W., 1960 b. Sodium regulation in the crayfish Astacus fluviatilis. II. Experiments with sodium-depleted animals. Journal of Experimental Biology, 37, 100-112.

BRYAN G.W., 1960 c. Sodium regulation in the crayfish Astacus fluviatilis. III. Experiments with $\mathrm{NaCl}$-loaded animals. Journal of Experimental Biology, 37, 113-128.

CORNISH C.J., 1902. Crayfish and trout. In : A naturalist on the Thames, 51-56, Seely and Co., London.

COSSINS A.R., 1973. Thelohania contejeani Henneguy, microsporidian parasite of Austropotamobius pallipes Lereboullet - an histological and ultrastructural study. Freshwater Crayfish, 1, 151-164.

COSSINS A.R., BOWLER K., 1974. A histological and ultrastructural study of Thelohania contejeani Henneguy (1892) (Nosematidae), microsporidian parasite of the crayfish Austropotamobius pallipes Lereboullet. Parasitology, 68, 81-91.

DEPARTMENT OF THE ENVIRONMENT, 1995. Biodiversity, The U.K. Steering Group Report, Vol. 2, Action Plans, H.M.S.O.

DUFFIELD J.E., 1933. Fluctuations in numbers amongst fresh-water crayfish, Potamobius pallipes Lereboullet. Journal of Animal Ecology, 2, 184-196.

DUFFIELD J.E., 1936. Fluctuations in numbers of crayfish. Journal of Animal Ecology, 4, 396.

ENVIRONMENT AGENCY, 1997. Leaflet - Freshwater Crayfish in Britain and Ireland.

FARIS R.C., 1936. Status of the crayfish. Irish Naturalists' Journal, 6, 80.

FIRKINS I., HOLDICH D.M., 1993. Thermal studies on three species of freshwater crayfish. Freshwater Crayfish, 9, 241-248.

FOSTER J., 1993. The relationship between refuge size and body size in the crayfish Austropotamobius pallipes (Lereboullet). Freshwater Crayfish, 9, 345-349.

FOSTER J., 1995. Factors influencing the distribution and abundance of the crayfish Austropotamobius pallipes (Lereboullet) in Wales and the Marches, U.K. Freshwater Crayfish, 8, 79-98.

FOSTER J., TURNER C., 1993. Toxicity of field simulated farm waste episodes to the crayfish Austropotamobius pallipes (Lereboullet), elevated ammonia and reduced oxygen concentrations. Freshwater Crayfish, 9, 249-258.

FOSTER J., SLATER F., 1995. A global review of crayfish predation with observations on the possible loss of Austropotamobius pallipes in the Welsh Wye due to plague. Freshwater Crayfish, 8, 589-613. 
GERSTFELDT G., 1859. Über die Flusskrebse Europas. Memoirs of the Academy of Sciences, St-Petersberg, 9, 549-589.

GLEDHILL T., SUTCLIFFE D.W., WILLIAMS W.D., 1993. British Freshwater Crustacea Malacostraca. 2nd edition. Freshwater Biological Association Scientific Publications 52, $173 \mathrm{p}$.

GODDARD J.S., HOGGER J.B., 1986. The current status and distribution of freshwater crayfish in Britain. Field Studies, 6, 383-396.

GORDON I., 1963. On the rostrum of British crayfish Astacus pallipes Lereboullet. Crustaceana, $5,234-238$.

GRANDJEAN F., SOUTY-GROSSET C., HOLDICH D.M., 1997 a. Mitochondrial DNA variation in four British populations of the white-clawed crayfish Austropotamobius pallipes pallipes, implications for management. Aquatic Living Resources, 10, 121-126.

GRANDJEAN F., SOUTY-GROSSET C., RAIMOND R., HOLDICH D.M., 1997 b. Geographical variation of mitochondrial DNA between European populations of the white-clawed crayfish Austropotamobius pallipes. Freshwater Biology, 37, 493-501.

GROOMBRIDGE B., 1993. 1994 IUCN Red List of Threatened Animals. IUCN, Gland and Cambridge. $286 \mathrm{p}$.

GUAN R.Z., 1994. Burrowing behaviour of signal crayfish, Pacifastacus leniusculus (Dana), in the River Great Ouse, England. Freshwater Forum, 4, 155-168.

GUAN R.Z., WILES P.R., 1996. Growth, density and biomass of crayfish, Pacifastacus leniusculus, in a British lowland river. Aquatic Living Resources, 9, 265-272.

GUAN R.Z., WILES P.R., 1997. The home range of signal crayfish in a British lowland river. Freshwater Forum, 8, 45-54.

HOGGER J.B., 1986 a. A report on some of the first introductions of Pacifastacus leniusculus into the U.K. Freshwater Crayfish, 6, 134-145.

HOGGER J.B., 1986 b. Aspects of the introduction of "signal crayfish» Pacifastacus leniusculus (Dana), into southern United Kingdom. 1. Growth and survival. Aquaculture, 58, 27-44.

HOGGER J.B., LOWERY R.S., 1982. The encouragement of freshwater crayfish populations by construction and maintenance of waterways. Journal of the Institute of Water Engineering and Science, 36, 214-220.

HOLDICH D.M., 1988. The dangers of introducing alien animals with particular reference to freshwater crayfish. Freshwater Crayfish, 7, 15-30.

HOLDICH D.M., 1991. The native crayfish and threats to its existence. British Wildlife, 2 (3), 141-161.

HOLDICH D.M., 1992. Crayfish nomenclature and terminology. Finnish Fisheries Research, 14, 157-159.

HOLDICH D.M., 1993. A review of astaciculture - freshwater crayfish farming. Aquatic Living Resources, 6 (3), 307-317.

HOLDICH D.M., 1996. Austropotamobius pallipes. in : van HELDDINGEN P.J., WILLEMSE I., SPEIGHT M.C.D. (eds), Background information on invertebrates of the Habitats Directive and the Bern Convention. Part 1 - Crustacea, Coleoptera and Lepidoptera, 2-8, Nature and environment, 79, Council of Europe Publishing, Strasbourg.

HOLDICH D.M., JAY D., GODDARD J.S., 1978. Crayfish in the British Isles. Aquaculture, 15, 91-97.

HOLDICH D.M., LOWERY R.S., 1988. Freshwater Crayfish - Biology, Management and Exploitation. Chapman and Hall, London. 498 p.

HOLDICH D.M., REEVE I.D., 1988. Functional morphology and anatomy. In : HOLDICH D.M., LOWERY R.S. (eds), Freshwater Crayfish - Biology, Management and Exploitation, 11-51, Chapman and Hall, London. 
HOLDICH D.M., REEVE I.D., 1991. The distribution of freshwater crayfish in the British Isles with particular reference to crayfish plague, alien introductions and water quality. Aquatic Conservation, 1 (2), 139-158.

HOLDICH D.M., ROGERS W.D., 1992. Crayfish populations in the British Isles, farming, legislation, conservation and management. Finnish Fisheries Research, 14, 23-32.

HOLDICH D.M., DOMANIEWSKI J.C.J., 1995. Studies on a mixed population of the crayfish Austropotamobius pallipes and Pacifastacus leniusculus in England. Freshwater Crayfish, 10, 37-45.

HOLDICH D.M., REEVE I.D., ROGERS W.D., 1995 a. Introduction and spread of alien crayfish in British waters - implications for native crayfish populations. Freshwater Crayfish, 8 , 99-112.

HOLDICH D.M., ROGERS W.D., READER J.P., 1995 b. Crayfish conservation. Project Record $378 / 10 / \mathrm{N}$ and $\mathrm{Y}$. National Rivers Authority, Bristol. $278 \mathrm{p}$.

HOLDICH D.M., ROGERS W.D., READER J.P., HARLIOGLU M.M., 1995 c. Interactions between three species of freshwater crayfish (Austropotamobius pallipes, Astacus leptodactylus and Pacifastacus leniusculus). Freshwater Crayfish, 10, 46-56.

HOLDICH D.M., HARLIOGLU M.M., FIRKINS I., 1997. Salinity adaptations of crayfish in British waters with particular reference to Austropotamobius pallipes, Astacus leptodactylus and Pacifastacus leniusculus. Estuarine, Coastal and Shelf Science, 44, 147-154.

HOLDICH D.M., ROGERS W.D., 1997. Strategy for the management of white-clawed crayfish (Austropotamobius pallipes) populations in England and Wales. Environment Agency $R$ and D Project $640.23 \mathrm{p}$.

HUXLEY T.H., 1878. On the classification and the distribution of the crayfishes. Proceedings of the Zoological Society of London, 1878, 751-788.

HUXLEY T.H., 1879. The crayfish - an introduction to the study of zoology. Keegan Paul, London. 371 p. (1974 edition published by The MIT Press, Cambridge, Massachusetts).

INGLE R.W., 1979. Laboratory and scuba studies on the behaviour of the freshwater crayfish, Austropotamobius pallipes (Lereboullet). Report of the Underwater Association, 2, 1-16.

INGLE R.W., THOMAS W., 1974. Mating and spawning of the crayfish Austropotamobius pallipes (Crustacea, Astacidae). Journal of Zoology, 173, 525-538.

JAY D., HOLDICH D.M., 1977. The effect of $\mathrm{pH}$ on the survival of Austropotamobius pallipes. Freshwater Crayfish, 3, 363-370.

JAY D., HOLDICH D.M., 1981. The distribution of the British freshwater crayfish, Austropotamobius pallipes (Lereboullet). Freshwater Biology, 11, 121-129.

LAURENT P.J., 1988. Austropotamobius pallipes and $A$. torrentium, with observations on their interactions with other species in Europe. In : HOLDICH D.M., LOWERY R.S. (eds), Freshwater crayfish, biology, management and exploitation, 341-364, Chapman and Hall, London.

LAURENT P.J., 1995. Eradication of unwanted crayfish species for astacological management purposes. Freshwater Crayfish, 8, 121-133.

LILLEY A.J., BROOKER M.P., EDWARDS R.W., 1979. The distribution of the crayfish, Austropotamobius pallipes (Lereboullet), in the upper Wye catchment, Wales. Nature Wales, 16, 195-200.

LOWERY R.S., 1988. Growth, moulting and reproduction. In : HOLDICH D.M., LOWERY R.S. (eds), Freshwater crayfish, biology, management and exploitation, 83-113, Chapman and Hall, London.

LOWERY R.S., HOGGER J.B., 1986. The effect of river engineering works and disease on a population of Austropotamobius pallipes in the River Lea, U.K. Freshwater Crayfish, 6, 94-99.

LOWERY R.S., HOGGER J.B., POLGLASE J.L., ALDERMAN D.J., 1986. Crayfish mortalities in the U.K. rivers. Freshwater Crayfish, 6, 234-238. 
LOWERY R.S., HOLDICH D.M., 1988. Pacifastacus leniusculus in North America and Europe, with details of the distribution of introduced and native crayfish species in Europe. In: HOLDICH D.M., LOWERY R.S. (eds), Freshwater crayfish, biology, management and exploitation, 283-308, Chapman and Hall, London.

LUCEY J., MCGARRIGLE M.L., 1987. The distribution of the crayfish Austropotamobius pallipes (Lereboullet) in Ireland. Irish Fisheries Investigations, Ser. A (29), 3-13.

MARREN P., 1986. The lethal harvest of crayfish plague. New Scientist, 109 (1493), 46-50.

MATTHEWS M.A., REYNOLDS J.D., 1990. Laboratory investigations of the pathogenicity of Aphanomyces astaci for Irish freshwater crayfish. Hydrobiologia, 203, 121-126.

MATTHEWS M.A., REYNOLDS J.D., 1992. Ecological impact of crayfish plague in Ireland. Hydrobiologia, 234, 1-6.

MATTHEWS M.A., REYNOLDS J.D., KEATINGE M.J., 1993. Macrophyte reduction and benthic community alteration by the crayfish Austropotamobius pallipes (Lereboullet). Freshwater Crayfish, 9, 289-299.

MATTHEWS M.A., REYNOLDS J.D., 1995 a. The in vitro culture of crayfish eggs using a recirculating airlift incubator. Freshwater Crayfish, 8, 300-306.

MATTHEWS M.A., REYNOLDS J.D., 1995 b. A population study of the white-clawed crayfish Austropotamobius pallipes (Lereboullet) in an Irish reservoir. Proceedings of the Royal Irish Academy, 95B, 99-109.

MCFADDEN Y.M.T., FAIRLY J.S., 1984. Food of otters Lutra lutra in an Irish limestone river system with special reference to the crayfish Austropotamobius pallipes. Journal of Life Sciences of the Royal Dublin Society, 5, 65-76.

MIDDLETON D., HOLDICH D.M., RATCLIFFE N.A., 1996. Haemagglutinins in six species of freshwater crayfish. Comparative Biochemistry and Physiology, 114 A, 143-152.

MINISTRY OF AGRICULTURE, FISHERIES AND FOOD, 1996. Leaflet - Crayfish Alert. Fish Markets, Restaurants, Hotels. MAFF Publications, London.

MORIARTY C., 1972. A study of Austropotamobius pallipes in Ireland. Freshwater Crayfish, 1 , $57-68$.

NATIONAL RIVERS AUTHORITY, 1994. Leaflet - A guide to identifying freshwater crayfish in Britain and Ireland. National Rivers Authority, Bristol.

NAURA M., ROBINSON M., 1997. Principles of using river habitat survey to predict aquatic species : an example applied to the white-clawed crayfish Austropotamobius pallipes. Aquatic Conservation (in press).

O'KEEFFE C., REYNOLDS J.D., 1983. The occurrence of crayfish diseases and their significance in Ireland. Freshwater Crayfish, 5, 299-306.

PIXELL GOODRICH H.P., 1956. Crayfish epidemics. Parasitology, 46, 480-483.

POND C.M., 1975. The role of the "walking legs" in aquatic and terrestrial locomotion of the crayfish Austropotamobius pallipes (Lereboullet). Journal of Experimental Biology, 62, 447-454.

PRATTEN D.J., 1980. Growth in the crayfish Austropotamobius pallipes (Lereb.). Freshwater Biology, 10, 401-412.

REYNOLDS J.D., 1979 a. The introduction of freshwater crayfish species for aquaculture in Ireland. In : KERNAN R.P., MOONEY O.V., WENT A.E.J. (eds), The introduction of exotic species : advantages and problems, 57-64, Royal Irish Academy, Dublin.

REYNOLDS J.D., 1979 b. Crayfish ecology in Ireland. Freshwater Crayfish, 4, 215-220.

REYNOLDS J.D., 1982. Notes on the Irish distribution of the freshwater crayfish. Bulletin of the Irish Biogeographical Society, 6, 18-24.

REYNOLDS J.D., 1988 a. Crayfish extinctions and crayfish plague in Ireland. Biological Conservation, 45, 279-285. 
REYNOLDS J.D., 1988 b. Options for crayfish culture and exploitation in Ireland. Freshwater Crayfish, 7, 327-331.

REYNOLDS J.D., 1989 a. Phenotypic variation in freshwater crayfish and its implications for aquaculture. In : ALDRICH J.C. (ed), Phenotypic responses and individuality in aquatic ectotherms, 197-201, Ashford, Co. Wicklow, Japaga.

REYNOLDS J.D., 1989 b. Crayfish culture and exploitation in Ireland. In : SKURDAL J., WESTMAN K., BERGAN P.I. (eds), Crayfish culture in Europe, 92-95, Directorate of Nature Management, Trondheim, Norway.

REYNOLDS J.D., MATTHEWS M.A., 1993. Experimental fishing of Austropotamobius pallipes (Lereboullet) stocks in an Irish midlands lake. Freshwater Crayfish, 9, 147-153.

REYNOLDS J.D., MATTHEWS M.A., 1997. Successful reintroduction of crayfish to Irish lake. Crayfish News, 19 (2), 4-5.

RHODES C.P., 1981. Artificial incubation of the eggs of the crayfish Austropotamobius pallipes (Lereboullet). Aquaculture, 25, 129-140.

RHODES C.P., HOLDICH D.M., 1979. On size and sexual dimorphism in Austropotamobius pallipes (Lereboullet). A step in assessing the commercial exploitation potential of the native British crayfish. Aquaculture, 17, 345-358.

RHODES C.P., HOLDICH D.M., 1982. Observations on the fecundity of the freshwater crayfish, Austropotamobius pallipes (Lereboullet) in the British Isles. Hydrobiologia, 89, 231-236.

RHODES C.P., HOLDICH D.M., 1984. Length-weight relationship, muscle production and proximate composition of the freshwater crayfish, Austropotamobius pallipes (Lereboullet). Aquaculture, 37, 107-123.

RICHARDS K.J., 1983. The introduction of the signal crayfish into the United Kingdom and its development as a farm crop. Freshwater Crayfish, 5, 557-563.

RICHARDS K.J., FUKE P., 1977. Freshwater crayfish - the first centre in Britain. Fish Farming International, 4, 12-15.

ROGERS W.D., HOLDICH D.M., 1995 a. Crayfish production in Britain. Freshwater Crayfish, 10, 583-596.

ROGERS W.D., HOLDICH D.M., 1995 b. Conservation and management of British crayfish populations. Freshwater Crayfish, 10, 92-97.

ROGERS W.D., HOLDICH D.M., 1997. New legislation to conserve the native crayfish in Britain - will it work ? Freshwater Crayfish, 11 (in press).

RUTTY J., 1772. An essay towards a natural history of the county of Dublin. Octavo, Dublin. $392 \mathrm{p}$.

SHAW J., 1959. The absorption of sodium ions by the crayfish, Astacus pallipes Lereboullet. I. The effect of external and internal sodium concentrations. Journal of Experimental Biology, 36, 126-144.

SHAW J., 1960 a. The absorption of sodium ions by the crayfish, Astacus pallipes Lereboullet. II. The effect of the external anion. Journal of Experimental Biology, 37, 534-547.

SHAW J., 1960 b. The absorption of sodium ions by the crayfish, Astacus pallipes Lereboullet. III. Effects of other cations in the external solution. Journal of Experimental Biology, 37, 548-556.

SHAW J., 1960 c. The absorption of chloride ions by the crayfish, Astacus pallipes Lereboullet. Journal of Experimental Biology, 37, 557-572.

SLATER F.M., 1995. A simple crayfish trap. Freshwater Crayfish, 10, 194-195.

SLATER F.M., FOSTER J., 1987. The Edw Lobster. Nature in Wales, 6, 75.

SLATER F.M., RAYNER G., 1993. Austropotamobius pallipes in otter diet in the mid-Wye catchment of central Wales. Freshwater Crayfish, 9, 365-367.

SLATER F.M., DAVIES C., FOSTER J., 1995. A non-invasive technique for monitoring the presence of crayfish in rivers, particularly in relation to crayfish plague. Freshwater Crayfish, 10 , 385-387. 
SMITH G.R.T., LEARNER M.A., SLATER F.M., FOSTER J., 1996. Habitat features important for the conservation of the native crayfish Austropotamobius pallipes in Britain. Biological Conservation, 75, 239-246.

SUTCLIFFE D.W., CARRICK T.R., 1975. Respiration in relation to ion uptake in the crayfish Austropotamobius pallipes (Lereboullet). Journal of Experimental Biology, 63, 689-699.

TAUGBøL T., SKURDAL J., HÅSTEIN T., 1993. Crayfish plague and management strategies in Norway. Biological Conservation, 63, 75-82.

TAYLOR E.W., WHEATLY M.G., 1980. Ventilation, heart rate and respiratory gas exchange in the crayfish Austropotamobius pallipes (Lereboullet) submerged in normoxic water and after $3 \mathrm{~h}$ exposure in air at 15० C. Journal of Comparative Physiology, 138, 67-78.

TAYLOR E.W., WHEATLY M.G., 1981. The effects of long-term aerial exposure on heart rate, ventilation, respiratory gas exchange and acid-base status in the crayfish Austropotamobius pallipes. Journal of Experimental Biology, 92, 109-124.

THIENEMANN A., 1950. Verbreitungsgeschichte der Süsswassertierwelt Europas. Die Binnengewässer, 18. Ferinand Enke Verlag, Stuttgart.

THOMAS W.J., 1970. The setae of Austropotamobius pallipes (Crustacea, Astacidae). Journal of Zoology, 160, 91-142.

THOMAS W.J., 1977. Crayfish reproductive structures. Freshwater Crayfish, 3, 453-461.

THOMAS W.J., 1979. Aspects of crayfish biology. Freshwater Crayfish, 4, 115-122.

THOMAS W.J., 1983. Dimorphism in the British crayfish Austropotamobius pallipes (Lereboullet). Freshwater Crayfish, 5, 12-17.

THOMAS W.J., 1986. The paragnaths of Austropotamobius pallipes. Freshwater Crayfish, 6, 42-47.

THOMAS W.J., 1992. A note on the crayfish of Loch Croispol. Glasgow Naturalist, 22, 107-109.

THOMAS W.J., INGLE R., 1971. The nomenclature, bionomics and distribution of the crayfish, Austropotamobius pallipes (Lereboullet) (Crustacea, Astacidae) in British waters. Essex Naturalist, 32, 349-360.

THOMPSON W., 1843. The Crustacea of Ireland. Annals \& Magazine of Natural History, 11, 102-111.

WHEATLY M.G., TAYLOR E.W., 1981. The effect of progressive hypoxia on heart rate, ventilation, respiratory gas exchange and acid-base status in the crayfish Austropotamobius pallipes. Journal of Experimental Biology, 92, 125-141.

WHITELEY N.M., TAYLOR E.W., de SOUZA S.C.R., EL HAJ A.J., 1993. Seasonal and moult related changes in haemolymph oxygen and acid-base levels in a wild population of Austropotamobius pallipes (Lereboullet). Freshwater Crayfish, 9, 189-199.

WOODLOCK B., REYNOLDS J.D., 1988 a. Laboratory breeding studies of freshwater crayfish, Austropotamobius pallipes. Freshwater Biology, 19, 71-78.

WOODLOCK B., REYNOLDS J.D., 1988 b. Reproduction in an Irish lake population of the crayfish Austropotamobius pallipes (Lereboullet). Freshwater Crayfish, 19, 79-86. 